\title{
Determinants of E-Commerce Adoption amongst SMMEs in Durban, South Africa
}

\author{
Mr Patrick Ndayizigamiye \\ University of KwaZulu-Natal, South Africa, School of Management, IT and Governance \\ Ndayizip@ukzn.ac.za \\ Professor Brian McArthur
}

University of KwaZulu-Natal, South Africa, School of Management, IT and Governance

McArthurb@ukzn.ac.za

\section{Doi:10.5901/mjss.2014.v5n25p250}

\section{Abstract}

In South Africa, the increasing number of cellphone internet users coupled with the growth of online shopping behaviour indicates that more South Africans are able to access the internet with the prospects of engaging with online businesses. Using the Diffusion of Innovation Theory (DOI), this paper examines the determinants of e-commerce adoption by South African SMMEs in the Durban area. The persuasion variables of the DOI (relative advantage, compatibility and complexity) were tested against four (4) e-commerce options namely, customers payment by credit card through the SMME's website, customers placing orders through the SMME's website, providing customer services through the SMME's website and placing orders with suppliers over the internet. Using convenience sampling, data was collected by means of a survey questionnaires administered to 200 SMME owners/managers. Usable responses were collected from 180 SMME owners/managers. This represents a $90 \%$ response rate. A Chi square test of independence was used to test the significance of association between the DOI variables and e-commerce adoption. Findings reveal that relative advantage and compatibility are the only DOI variables that significantly influence the decision to adopt e-commerce in Durban. Specifically, improving information exchange with customers, easier access to international markets, expansion of business reach, reduction of costs of maintaining up to-date company information and improving information exchange with suppliers are significant factors that inform the decision to adopt e-commerce in Durban. In addition, compatibility with existing company's technology infrastructure and compatibility with company values significantly affect SMMEs' decision to place orders with suppliers through the internet. Interestingly, the adoption of the other e-commerce options (online payment by credit card, online ordering and online customer services) is not significantly influenced by compatibility. The findings imply that in order to increase SMMEs' e-commerce adoption, SMMEs need to be better acquainted with the benefits that derive from its adoption. Moreover, a stepwise approach to e-commerce adoption is advised, starting with e-commerce options that are compatible with SMMEs technology infrastructure and values then gradually moving to more sophisticated e-commerce options.

Keywords: e-commerce adoption, South Africa, SMME, Diffusion of innovation (DOI)

\section{Introduction}

The development of an ICT-enabled and networked SMME sector through affordable but effective ICT solutions can enable developing countries to achieve rapid and sustainable economic and social development (Kotelnikov, 2007). Importantly, e-commerce technologies enable organisations to improve their internal business processes and communications, and their communications with external trading partners (Chong, 2006). In view of the predominant role of e-commerce in sustainable SMMEs' development, it is important to identify strategies that may encourage SMMEs to adopt e-commerce. In this context, the knowledge of factors that influence e-commerce adoption in South Africa is necessary. Specifically, the knowledge of the perceived advantage and complexity of e-commerce would enable the simplification of e-commerce solutions in a way that encourages SMMEs to adopt e-commerce to achieve the perceived results. In addition, there is also a need to design e-commerce solutions that are consistent with the values and previous experiences of SMMEs. Hence, there is a need to know what compatibility factors would significantly affect the adoption of e-commerce by South African SMMEs. 


\section{Literature Review}

\subsection{E-commerce adoption by SMMEs}

The Organisation for Economic Development (OECD, 2000) contends that the e-commerce environment comprises either start-up firms designed to operate on the internet or established firms that seek to explore the e-commerce platform. Although start-up e-commerce benefits might be very small, e-commerce offers the possibility of reaching a wide range of markets ( Vaithianathan, 2010). E-commerce influences the growth and expansion of firms in developing countries as it reduces the cost of transactions (Molla and Licker, 2005). The internet platform eliminates distribution and marketing barriers that prevail in a traditional business environment (OECD, 2000). Small firms are better able to adopt ecommerce, as they are not bound by legacy technology compared to larger firms (OECD, 2000). Moreover, generally, SMMEs are not strongly tied to traditional retail channels. Hence, SMMEs are more flexible and able to innovate and adapt to rapid change (OECD, 2000). This is a distinctive advantage, which makes it easier for SMMEs to implement a business model aligned with e-commerce adoption.

Curran and Blackburn (2001) advocate that SMMEs are the cornerstone of modern economies. In the United Kingdom (UK), Small and medium sized enterprises (SMMEs) play an important part in the UK economy, accounting for 99\% of the nation's business enterprises and contribute to over half of employment (58.9\%) and turnover (51.9\%) (Dyerson, Harindranath and Barnes, 2009). The Australian government also recognizes that SMMEs are the centre of economic potential (NOIE, 2002). In South Africa, SMMEs play a critical role in the country's economy. SMMEs contribute between $52 \%$ and $57 \%$ of the country's GDP and up to $61 \%$ of the overall employment in South Africa (Abhor and Quartey, 2010). Thus, by adopting e-commerce, SMMEs will take advantage of the benefits described above and contribute to third world countries' development and poverty alleviation.

\subsection{Internet adoption in South Africa}

The number of South Africans using broadband connections increased by $50 \%$ between 2009 and 2010 (BrandSouthAfrica, 2011). This considerable growth in broadband connections has been mainly observed in Small and Medium businesses as most of them have upgraded to ADSL broadband connections (BrandSouthAfrica, 2011). In March 2012, there were approximately 3.5 million broadband connections in South Africa (Doc, 2012). ADSL broadband connections counted for 26\% (850,000 connections), $69 \%$ were 3G/HSPA mobile wireless broadband based (Doc, 2012). In mid-2012, it was estimated that "74\% of schools, $81 \%$ of health facilities and $83 \%$ of police stations had broadband coverage" (Doc, 2012:3).The increase in the number of internet users has also been triggered by the diminishing Telecom ${ }^{1}$ monopoly. Currently, Electronic Communications Network Services licenses have been issued to over 400 companies (BrandSouthAfrica, 2011). Thus, internet service providers can build their own networks instead of relying on a single service provider. This has led to access to the internet at a cheaper cost in South Africa.

Goldstuck (2009) argues that the growth of cell phone internet offers potential for further internet growth in South Africa. In 2011, about 6 million South Africans had internet access on their phones (WorldWideWorx, 2011a). The increasing access to the internet offers business opportunities, particularly within the SMME sector. Goldstuck (WorldWideWorx, 2011b) notes an increase in online sales in South Africa. According to a study on online retail in South Africa (WorldWideWorx, 2011b), South Africans spent two (2) billion rands buying goods online in 2010. The projected growth of online spending was 40\% for 2011 (WorldWideWorx, 2011b). SMMEs need to take advantage of such growth by having an online presence. Goldstuck (WorldWideWorx, 2011c) advocates that it is crucial for SMMEs to have an "effective online presence". He argues "already, many consumers turn to browsers and search engines for assistance in finding the right product or service. This can be expected to increase exponentially as more people access the internet on their phones. Therefore, those SMMEs that are not online, or that have a limited or ineffective presence, could suffer" (WorldWideWorx, 2011c).

\section{Theoretical Framework}

\subsection{The Diffusion of Innovation (DOI) theory}

The diffusion of innovation depicts the "decision-making process that occurs through a series of communication channels

${ }^{1}$ South African State-owned Telecommunications company 
over a period of time" (Rogers, 2003:5). In essence, the theory provides a conceptual framework through which a new technology is adopted and spreads across a social system. According to the DOI theory, the adoption process starts with the knowledge phase (see figure 1) whereby the adopter becomes acquainted with the existence of a technology and learns about it. The adoption process graduates into a second stage which is persuasion. At this stage, the potential adopter collects information about the innovation and makes a judgment on the perceived benefits (utility) of the innovation.

Figure 1: Diffusion of innovation theory

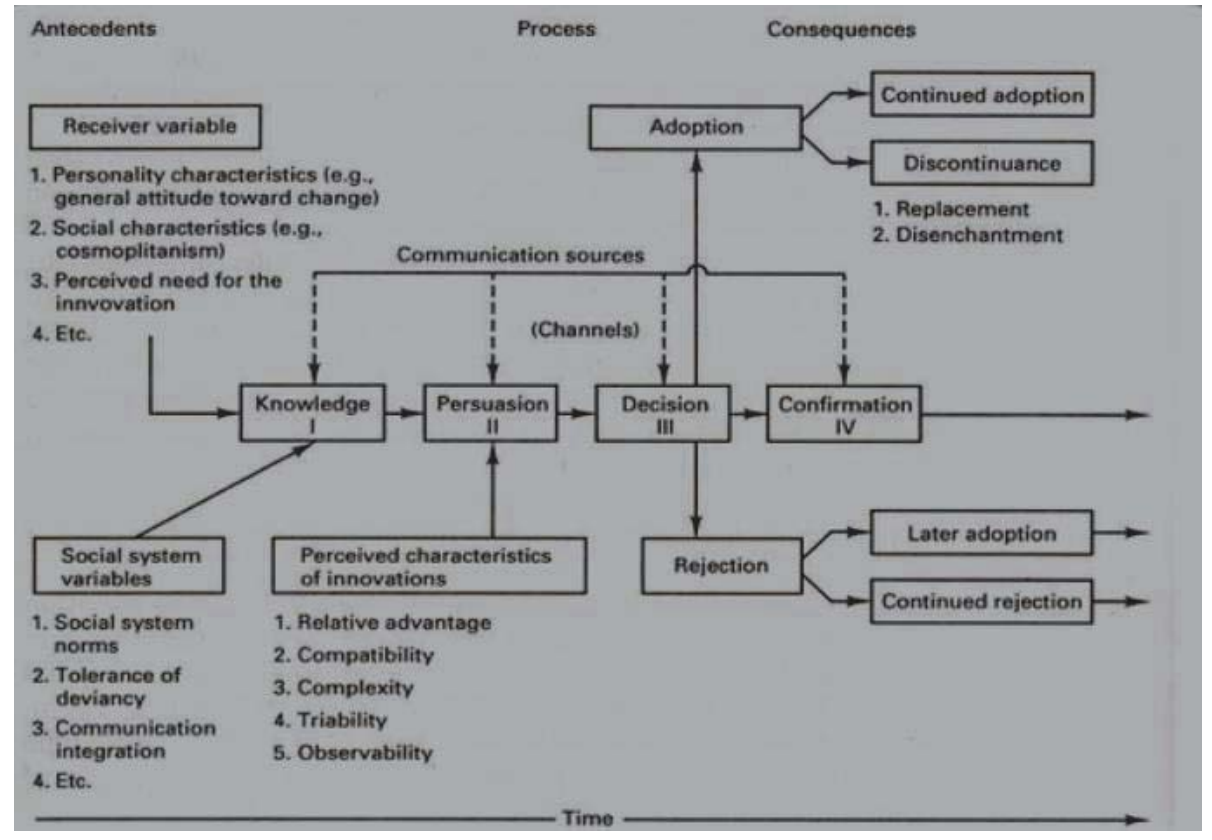

Rogers (1995 ) identifies five major determinants at this stage of persuasion: relative advantage, compatibility, complexity, trialability and observability (see figure 1).

Relative advantage refers to the perceived benefits of a new technology compared to its predecessor. In this case, potential adopters seek to know the extent to which a new innovation is better than an existing technology. Compatibility refers to the perception of the innovation's consistency with the values, previous experiences and needs of potential adopters. Compatibility refers particularly to how close the innovation fits into the individual's situation. Complexity, according to Rogers (1995:247), relates to "the degree to which an innovation is perceived as relatively difficult to understand and use."Trialability refers to the extent to which an innovation can be tried before its implementation. Observability is the degree to which the results of an innovation are visible to others.

The decision phase in the $\mathrm{DOI}$ theory yields two main possible outcomes. A positive outcome will result in the adoption of the innovation permanently. A variation of the positive outcome is discontinuance which is defined as the rejection of the innovation after being previously adopted. Conversely, a negative outcome will lead to the rejection of the innovation with possibilities of later adoption or permanent discarding of the innovation's implementation option.

The five determinants of the persuasion stage (relative advantage, compatibility, complexity, trialability and observability) have been used in a number of previous studies. Although the focus of Rogers' model has been at an individual level, there is evidence that the model can be applied to IT implementation in business organisations (Attewell, (1992); Brancheau, (1990)). In the context of this study, relative advantage, compatibility and complexity variables are tested as potential determinants of e-commerce adoption by Durban SMMEs. These three variables have been used extensively in previous research. Thus, their relevance within the context of SMMEs has been demonstrated. For instance, Chong et al. (2001), applying Rogers' model to small and medium businesses in Australia, concluded that complexity, perceived relative advantage, and compatibility are important factors that need to be considered in order to implement successful internet-based electronic commerce, the first factor being the most significant contributing factor to e-commerce adoption 


\section{Methodology}

A survey was conducted amongst Durban SMMEs. Data was collected by means of questionnaires administered to 200 SMMEs' owners/managers randomly sampled. Usable responses were collected from 180 owners/managers. This represents a 90\% output rate. The following variables were tested as part of the persuasion phase constructs:

Relative advantage: The relative advantage factor served to test whether the following e-commerce benefits are applicable within the context of Durban SMMEs. These are: i)Improving information exchange with customers (RA1), ii) increasing customer loyalty and retention (RA2), iii) improving service to the customer (RA3), iv) easier access to international markets (RA4), v) expansion of business reach (RA5), vi) reduction of costs of maintaining up-to-date company information (RA6), vii) improving information exchange with suppliers (RA7), viii) reducing costs through web based purchasing and procurement (RA8), ix) improving the competitive position of your company (RA9), $x$ ) attracting new investment to the company (RA10).

The influence of compatibility as a determinant of e-commerce adoption in Durban was tested through the following variables: i) compatibility with company business processes (COMPAT1), ii) compatibility with existing company's technology infrastructure (COMPAT2), iii) compatibility with existing company's organisational culture (COMPAT3), iv) compatibility with company values (COMPAT4), v) compatibility with company's preferred work practices (COMPAT5).

The influence of complexity as a determinant of e-commerce in the surveyed SMMEs was tested through the following variables: i) learning to operate e-commerce is easy (COMPLEX1), ii) e-commerce is flexible to interact with (COMPLEX2), iii) the interaction with e-commerce is clear and understandable (COMPLEX3), iv) it is easy to become skillful at using e-commerce (COMPLEX4), v) e-commerce requires basic computer skills (COMPLEX5), vi) expert skills are needed to use e-commerce (COMPLEX6).

\section{Results and Discussion}

In order to test the significance of the DOI variables as possible determinants of e-commerce in the Durban area, a chi square of independence (test of association) was used.

\subsection{Association between relative advantage and e-commerce adoption}

The following hypotheses were formulated in order to test the relationship between relative advantage and each one of the four e-commerce options:

$\mathrm{H}_{0}$ : There is no relationship between relative advantage and e-commerce adoption

$\mathrm{H}_{1}$ : There is a relationship between relative advantage and e-commerce adoption

The relationship between the relative advantage variables described above and each one of the four e-commerce options was tested by means of a Chi square test of independence. Table 1 below shows that in Durban, the following significant relationships were found:

- There is a significant relationship between RA1 and online payment by credit card, RA1 and online ordering,

- There is a significant relationship between RA4 and all the four e-commerce options,

- RA5 is significantly related to online payment by credit card only,

- RA6 is significantly related to all of the four e-commerce options except online ordering,

- RA7 is significantly related to online payment by credit card only, and

- RA10 is significantly related to online ordering and customer services only.

A closer look at the crosstabulation between the relative advantage variables and each one of the e-commerce options reveals that, in Durban, for significant relationships $(p<0.05)$ there are more than expected SMMEs that consider the above relative advantage variables to be very important for their companies, based on their current and anticipated business requirements. This suggests that the relative advantage variables could have influenced the decision to adopt ecommerce in Durban. Kirby and Turner (1993) argue that the perception of the usefulness of a technology is often related to the knowledge that the owner has about the use of such technology. In the context of this research, this could mean that those that adopted e-commerce were aware of the benefits of e-commerce prior or after adopting e-commerce Thus, this research re-emphasizes the importance of SMME owners' knowledge of the benefits of e-commerce within each individual SMME's context. This knowledge will then inform the type of e-commerce option to adopt in relation to the SMME's business strategy. The influence of the relative adavantage on e-commerce adoption was previously confirmed 
by the findings by Mirchandani and Motwani (2001) study on e-commerce adoption by small businesses.

Table 1: Summary of Chi square tests between relative advantage and e-commerce adoption

\begin{tabular}{|c|c|c|c|c|}
\hline & Online payment by credit card & Online ordering & Customer services & Placing orders with suppliers through the internet \\
\hline RA1 & $0.013^{* *}$ & $0.048^{* *}$ & $0.093^{* *}$ & $0.351^{* *}$ \\
\hline RA2 & $0.204^{* *}$ & $0.085^{* *}$ & $0.782^{* *}$ & $0761^{* *}$ \\
\hline RA3 & $0.233^{* *}$ & $0.892^{* *}$ & $0.834^{* *}$ & $0.626^{* *}$ \\
\hline RA4 & 0.004 & 0.04 & 0.001 & 0.004 \\
\hline RA5 & $0.043^{* *}$ & $0.245^{* *}$ & $0.116^{* *}$ & $0.086^{* *}$ \\
\hline RA6 & $0.005^{* *}$ & $0.112^{* *}$ & $0.015^{* *}$ & $0.003^{* *}$ \\
\hline RA7 & $0.030^{* *}$ & $0.087^{* *}$ & $0.322^{* *}$ & $0.313^{* *}$ \\
\hline RA8 & $0.070^{* *}$ & $0.122^{* *}$ & $0.044^{* *}$ & 0.070 \\
\hline RA9 & $0.278^{* *}$ & $0.416^{* *}$ & $0.164^{* *}$ & $0.260^{* *}$ \\
\hline RA10 & $0.057^{* *}$ & $0.030^{* *}$ & 0.047 & $0.173^{* *}$ \\
\hline
\end{tabular}

${ }^{*} p<0.05=$ significant relationship; $p>=0.05=$ no significant relationship

${ }^{\star *}$ Fisher's test (more than $20 \%$ of data has count less than 5 )

\subsection{Association between compatibility and e-commerce adoption}

The following hypotheses were formulated in order to test the relationship between compatibility variables and each one of the e-commerce options:

$\mathrm{H}_{0}$ : There is no relationship between compatibility and e-commerce adoption

$\mathrm{H}_{1}$ : There is a relationship between compatibility and e-commerce adoption

The summary presented in table 2 below indicates that in Durban, the relationship between placing orders with suppliers through the internet and i) compatibility with existing company's technology infrastructure, ii) compatibility with company values are the only significant relationships. More specifically, the majority $(54.1 \%, \mathrm{~N}=59)$ of SMMEs that place orders with suppliers over the internet agree that compatibility with existing company infrastructure has influenced the decision to adopt e-commerce in their companies. Grandon and Pearson (2004) also found that compatibility with technology infrastructure has an influence on e-commerce adoption by SMMEs in Chile . In addition, the majority (68.2\%, $\mathrm{N}=75$ ) of SMMEs that place orders with suppliers over the internet agree that compatibility with company values has influenced the decision to adopt e-commerce in their companies. Hence, this study re- emphasizes the importance of these factors as determinants of e-commerce adoption within the South African context. E- Commerce adoption by SMMEs was found to be influenced by compatibility issues in other studies such as Hong and Zhu (2006), Saffu, Walker and Hinson, (2008). Similarly, Seyal, Awais, Shamail and Abbas (2004) found that organisational culture is a significant factor that influences the adoption of e-commerce in Pakistan SMMEs. Beatty, Shim and Jones (2001) also found that organisations that perceive website use as compatible with the existing organisational culture, adopted e-commerce earlier than those perceiving some level of incompatibility between the two. Gibbs, Kraemer and Dedrick (2003) and Teo and Ranganathan (2004) also found that organisational cultures that do not support innovation and the use of new technologies act as a barrier to Business to Business e-commerce adoption.

Table 2: Summary of Chi square tests between compatibility and e-commerce adoption.

\begin{tabular}{|l|c|c|c|c|}
\hline & Online payment by credit card & Online ordering & Customer services & Placing orders with suppliers through the internet \\
\hline Compat 1 & $0.376^{\star \star}$ & $0.376^{\star \star}$ & $0.49^{\star \star}$ & $0.257^{\star \star}$ \\
\hline Compat 2 & $0.310^{\star \star}$ & $0.397^{\star \star}$ & $0.860^{\star \star}$ & $0.003^{\star \star}$ \\
\hline Compat 3 & $0.969^{\star \star}$ & $0.076^{\star \star}$ & $0.497^{\star \star}$ & $0.180^{\star \star}$ \\
\hline Compat 4 & $0.501^{\star \star}$ & $0.246^{\star \star}$ & $0.315^{\star \star}$ & $0.032^{\star \star}$ \\
\hline Compat 5 & $0.080^{\star \star}$ & $0.300^{\star \star}$ & $0.588^{\star \star}$ & $0.509^{\star \star}$ \\
\hline
\end{tabular}

${ }^{*} p<0.05=$ significant relationship; $p>=0.05=$ no significant relationship

**Fisher's test (more than $20 \%$ of data has count less than 5 ) 


\subsection{Association between complexity and e-commerce adoption}

The following hypotheses were formulated:

$\mathrm{H}_{0}$ : There is no relationship between complexity and e-commerce adoption

$\mathrm{H}_{1}$ : There is a relationship between complexity and e-commerce adoption

Table 3 below indicates that there is no significant relationship between complexity and e-commerce adoption in Durban. This is in contrast with findings from other studies such as Chong, Pervan and Bauer (2001).

Table 3. Summary of Chi square tests between complexity and e-commerce adoption.

\begin{tabular}{|c|c|c|c|c|}
\hline & $\begin{array}{c}\text { Online payment by credit } \\
\text { card }\end{array}$ & $\begin{array}{c}\text { Online } \\
\text { ordering }\end{array}$ & $\begin{array}{c}\text { Customer } \\
\text { services }\end{array}$ & $\begin{array}{c}\text { Placing orders with suppliers } \\
\text { through the internet }\end{array}$ \\
\hline Complex 1 & $0.938^{\star \star}$ & $0.874^{\star \star}$ & $0.680^{\star \star}$ & $0.155^{\star \star}$ \\
\hline Complex 2 & $0.748^{\star \star}$ & $0.780^{\star \star}$ & $0.818^{\star \star}$ & $0.556^{\star \star}$ \\
\hline Complex 3 & $0.764^{\star \star}$ & $0.662^{\star \star}$ & $1.000^{\star \star}$ & $0.748^{\star \star}$ \\
\hline Complex 4 & $0.303^{\star \star}$ & $0.348^{\star \star}$ & $0.862^{\star \star}$ & $0.519^{\star \star}$ \\
\hline Complex 5 & $0.785^{\star \star}$ & $0.847^{\star \star}$ & $1.000^{\star \star}$ & $0.744^{\star \star}$ \\
\hline Complex 6 & $0.792^{\star \star}$ & $0.342^{\star \star}$ & $0.712^{\star \star}$ & $0.680^{\star \star}$ \\
\hline
\end{tabular}

${ }^{*} p<0.05=$ significant relationship; $p>=0.05=$ no significant relationship

${ }^{* *}$ Fisher's test (more than $20 \%$ of data has count less than 5 )

\section{Conclusion and Recommendations}

In summary, relative advantage, compatibility and complexity are the variables from the Diffusion of Innovation theory that have been tested in this study. The variables were tested in order to determine their influences on e-commerce adoption in Durban. It was found that relative advantage is significantly related to e-commerce adoption. Thus, there is a need for SMME owners to be acquainted with the various benefits of e-commerce in order to stimulate its adoption. Particularly, such awareness could be initiated as part of the South African government's functional interventions to stimulate the sustainable establishment of SMMEs. Furthermore, compatibility with existing company's technology infrastructure and compatibility with company values are significantly related to the adoption of e-commerce. Therefore, a stepwise approach towards the adoption of E-commerce is hereby suggested. The aim is to start with simple e-commerce applications that are aligned with the existing company's technology infrastructure and company values and then gradually move towards more complex e-commerce applications. However, the transition from simple to complex ecommerce applications should be facilitated by training and consultation with various stakeholders in the adoption and dissemination of e-commerce.

\section{References}

Abhor, J. \& Quartey, P. (2010). Issues in SME Development in Ghana and South Africa.International Research Journal of Finance and Economics, ISSN 1450-2887.

Attewell, P. (1992). Technology diffusion and organisational learning: The case of business computing. Organisation science, 3, 60-95.

Beatty, R. C., Shim, J. P. \& Jones, M. C. (2001). Factors influencing corporate web site adoption: a time-based assessment. Information and Management, 38, 337-354.

Brancheau, J. C., Wetherbe, J.C. (1990). The adoption of spreadsheet software: testing innovation diffusion theory in the context of enduser computing. Information Systems Research, 1, 123-39

Brandsouthafrica (2011).South Africa's telecommunications. [Online] Available: http://www.safrica.info/business/economy/infrastructure/ telecoms.htm (January05, 2011).

Brandsouthafrica(2012).Undersea cables and connectivity.[Online] Available: http://www.southafrica.info/business/economy/ infrastructure/telecoms.htm (February 06, 2013).

Chong, S., Pervan, G. \& Bauer, C. (2001). Implementation Success of internet-based Electronic Commerce for small and Medium Sized Enterprises in Australia. 14th International Bled Electronic Commerce Conference, June 25-26.

Chong, S. (2006). An Empirical Study of Factors that Influence the Extent of Deployment ofElectronic Commerce for Small- and Medium sized Enterprises in Australia.Journal of Theoretical and Applied Electronic Commerce Research, 1, 45-57.

Curran, J. \& Blackburn, R. (2001).Researching the Small Enterprise. London: Sage.

Doc, T. (2012).Broadband Presentation.[Online]Available: www.doc.gov.za/index.php?option=com_docman\&amp;task=doc_ download\&amp;gid=173\&amp;Itemid=104 (February 10, 2013). 
Dyerson, R., Harindranath, G. \& Barnes, D. 2009. National Survey of SMEs' Use of IT in Four Sectors. The ElectronicJournal Information Systems Evaluation, 12, 39- 50

Gibbs, J., Kraemer, K. L. \& Dedrick, J. 2003. Environment and policy factors shaping global E-commerce diffusion: A cross-country comparison. Inf. Soc., 19, 5-18

Goldstuck, A. (2009). Internet access to double in next five years. World Wide Worx.

Goldstuck, A. (2012). Internet Matters: The Quiet Engine of the South African Economy. [Online] Available: http://hsf.org.za/resourcecentre/focus/focus-66/AGoldstuck.pdf(August 15, 2012).

Grandon, E. \& Pearson, J. M. (2004). E-Commerce adoption: Perceptions of managers/owners of Small and Medium Sized Firms in Chile. Communications of the Association for Information Systems, 13, 81-102.

Hong, W. \& Zhu, K. (2006). Migrating to internet-based e-commerce: factors affecting E- commerce adoption and migration at the firm level. Information and Management, 43, 204-221.

Kotelnikov, V. (2007).Small and Medium Enterprises and ICT.e-Primers for the Information Economy, Society and Polity. [Online] Available:www.unapcict.org/.../small-and-medium-enterprises-and-ICT (April 20, 2012)

Kirby, D. \& Turner, M. (1993). IT and the small retail business. International Journal of Retail and Distribution Management, 21, 20-27

Molla, A., \& Licker, P. S. (2005) "e-Commerce adoption in developing countries: a model and instrument", Information and Management, Vol. 42 (6), pp. 877-899

Mirchandani, A. A. \& Motwani, J. (2001). Understanding small business electronic commerce adoption: an empirical analysis. Journal of Computer Information System, 70-73.

NOIE (2002). Better services, Better Government. [Online] Available:http://www.finance.gov.au/agimoarchive/_data/assets/ pdf_file/0016/35503/Better_Services-Better_Gov.pdf (April 20, 2012).

OECD. (2000). Realising the potential of electronic commerce for SMEs in the global economy. In: OECD (Eds). Conference for Ministers responsible for SMEs and Industry Ministers, 2000. Bologna: OECD.

Premkumar, G. \& Potter, M. (1995). Adoption of computer aided software engineering (CASE) technology: an innovation adoption perspective. Database, 26, 105-123

Rogers, E. (1995) Diffusion on Innovation. New York: Free Press.

Saffu, K., Walker, J. H. \& Hinson, R. (2008). Strategic value and electronic commerce adoption among small and medium-sized enterprises in a transitional e-conomy. The Journal of Business and Industrial Marketing, 23, 395-404

Seyal, A. H., Awais, M. M., Shamail, S. \& Abbas, A. (2004). Determinants of Electronic Commerce in Pakistan: Preliminary Evidence from Small and Medium Enterprises. Electronic Markets, 14, 372-387

Teo, T. \& Ranganathan, C. 2004. Adopters and non-adopters of business-to-business electronic commerce in Singapore. Information and Management, 42, 89-102.

UNCTAD (2001).E-Commerce and Development Report. New York: United Nations.

Vaithianathan, S. (2010) A review of e-commerce literature on India and research agenda for the future. Electronic Commerce Research 10, 83-97 [Online] Available: http://download.springer.com/static/pdf/186/art\%253A10.1007\%252Fs10660-010-90460.pdf?auth66=1413054090_7f2841caa47231fd4cc5f7b80876b456\&ext=.pdf (October 11, 2014).

Worldwideworx. (2011a). S.A. cellphone users embrace Internet. [Online] Available: http://www.worldwideworx.com/?p=294 (January 05, 2011).

Worldwideworx.(2011b). Online sales accelerate in SA. [Online] Available: http://www.worldwideworx.com/2011/05/12/online-salesaccelerate-in-sa/ (January05, 2011).

Worldwideworx.(2011c). Web sites crucial for SMEs. [Online] Available: http://www.worldwideworx.com/?p=363 (January05, 2011). 